\title{
LITERATURE STUDIES: BLENDED LEARNING ASSISTED BY EDMODO TO INCREASE STUDENT INDEPENDENCE AND LEARNING OUTCOMES
}

Elvina Irawati Sihite

Department of Science Education Universitas Negeri Medan

elvinairawatisihite@gmail.com

Accepted: November $3^{\text {th }}, 2021$. Published: December $31^{\text {th }}, 2021$

\begin{abstract}
The purpose of this research is to elaborate a number of thoughts and concepts that believe in the effect of applying Edmodo-assisted blended learning to improve student independence and learning outcomes. The research method used is literature study by collecting literature sourced from books, journals and other scientific sources related to Edmodo-assisted blended learning, independent learning and student learning outcomes. Based on the results of the study, blended learning was carried out by combining various methods of delivering learning with the help of online learning media, namely face-to-face and the use of e-learning. Edmodo facilitates teachers and students to be able to communicate, collaborate and carry out the learning process, teachers can provide learning content, and students can conduct discussions and collect assignments or homework anytime and anywhere. There are seven indicators of learning independence, namely: self-confidence, able to work alone, able to make decisions, be responsible, have a desire to compete, be disciplined and active in learning. Learning outcomes are divided into three domains, namely cognitive, affective, and psychomotor. The results of the study concluded that the use of Edmodo-assisted blended learning could increase students' independence and learning outcomes. disciplined and active in learning. Learning outcomes are divided into three domains, namely cognitive, affective, and psychomotor. The results of the study concluded that the use of Edmodo-assisted blended learning could increase students' independence and learning outcomes. disciplined and active in learning. Learning outcomes are divided into three domains, namely cognitive, affective, and psychomotor. The results of the study concluded that the use of Edmodo-assisted blended learning could increase students' independence and learning outcomes.
\end{abstract}

Keywords: Blended learning, edmodo, independent learning, student learning outcomes 


\section{Introduction}

Science and technology (science and technology) continues to develop in line with human civilization that continues to develop, so that the field of education also undergoes significant changes. Education is a means or space to develop the personality and potential that exists in students in accordance with the values that apply in social life so that they experience changes for the better.

The education system in Indonesia has changed since the policy of limiting activities outside the home was imposed due to the outbreak of the infectious disease Corona virus disease 2019 (Covid-19). Since mid-March 2020, learning that was originally conducted face-to-face in schools has turned into learning that is entirely done online as an effort to prevent the spread of the virus. Learning that is done entirely online also creates problems, students tend to be lazy and feel less confident to study on their own.

Learning objectives can be achieved well if students have high learning independence with the initiative and desire to learn from themselves will encourage students to carry out learning activities well. According to Fisher (2001) learning independence is an instructional method used in education where students have a sense of responsibility to carry out their own learning activities. Independent learning is a learning activity carried out by students with their own initiative and willingness. High learning independence affects student learning outcomes, students who have high learning independence tend to be more active in learning so that learning outcomes also increase.

Dewi's research (2020) shows that there is a positive influence of learning independence on learning outcomes, so student learning independence needs to be developed to maximize learning outcomes. Learning outcomes according to Slameto (2010) are the abilities students have after receiving learning experiences so that there is an increase in knowledge from those who do not know to know.

Based on these problems, it is necessary to apply a learning that is able to improve the quality of students, especially in increasing independence and science learning outcomes. One alternative that can be done is to apply blended learning. Graham (2005) states that blended learning is a combination of a face-to-face learning system with e-learning that can be used anywhere and anytime. Blended learning that combines face-to-face learning and elearning is a new innovation in delivering material so that students become more interested in learning.

According to Husama (2013) blended learning has the advantage that learning is more effective and efficient because students can more easily access learning and carry out learning even outside of face-to-face learning hours in class. In line with the results of Fahrulliah's research (2019), it proves that the application of the blended learning model in science learning can increase student learning independence and improve learning achievement. One application that can be used to support blended learning is Edmodo.

Edmodo is one type of LMS application. Learning Management System (LMS) is a virtual class that makes learning flexible so that the delivery of material from teacher to student can be done at any time synchronously or asynchronously. Edmodo is a safe and free social network-based application or web that can help make it easier for teachers to create virtual classes. Edmodo facilitates teachers and students to continue to communicate, collaborate and carry out the learning process, teachers can provide learning content, and students can conduct discussions and collect assignments or homework. Edmodo is equipped with several features for learning activities, such as quizzes, assignments, polls, grade books, libraries, award badges, and parent codes,

The various features make the use of Edmodo one of the strategies that can be done to increase learning independence and student learning outcomes. The use of Edmodo with the existence of varied features on Edmodo makes learning through online classes more structured, which leads students to take more initiative in the learning process, such as accessing the learning provided by the teacher on the Edmodo LMS and doing every task that has been provided on Edmodo. The application of blended learning assisted by Edmodo was chosen because it can increase student learning independence in learning, supported by student responses measured through a response questionnaire to the use 
of Edmodo media in learning which is in the high category (Aulia, 2019).

Based on the description above, the use of Edmodo as a medium in blended learning provides the advantage that teachers can easily plan and prepare online classes and the various features available in Edmodo provide encouragement for students to enjoy learning.

\section{Research Method}

The research method that used on this study was a literature study. The literature method is a series of activities related to the collection of library data, and other references related to the object under study. Therefore, this type of research will collect and review from the previous scientific literature (Sugiyono, 2019).

Researchers collect literature sourced from books, journals, and other scientific sources related to Edmodo-assisted blended learning and independent learning and student learning outcomes.

\section{Result and Discussion}

\section{E-learning}

E-learning which stands for Electronic Learning, is a new way in the teaching and learning process that uses electronic media, especially the internet as a learning system. The use of technology for educational development with the concept of utilizing e-learning can change the conventional education process to digital form so as to make learning more varied and become one of the triggers for attracting students to study harder. Daryanto (2013) states that "e-learning is a learning system that uses the help of electronic media as a tool for learning activities". It is concluded that e-learning is an educational system or concept that utilizes the use of information technology in the teaching and learning process.

\section{Blended Learning}

Blended learning comes from the words blended and learning. blend means to mix and learning means to learn. Blended learning combines face to face learning in the classroom and online learning to increase active independent learning by students and reduce the amount of face to face time in class. According to Husamah (2013), blended learning is learning that combines various delivery methods, teaching models, and various technological media.

Thorne (2003) states that blended learning is a conventional classroom where teachers and students meet face-to-face, with online learning that can be accessed anytime and anywhere. Prihadi (2013) states that blended learning is learning that combines all forms of learning, such as online, live, or face-to-face or conventional. Graham (2005) suggests that blended learning is learning that combines various modalities of learning media, learning methods, learning theories, and pedagogical dimensions and combines face-to-face learning with online learning.

From some of the opinions above, it can be concluded that blended learning is learning that utilizes information technology in the form of e-learning as a medium in delivering learning to improve student learning outcomes with more modern and interesting learning.

\section{Characteristics of Blended Learning}

Blended learning is carried out by combining various methods of delivering learning with the help of online learning media, namely face-to-face and the use of elearning. Carman (2005) states that there are five keys in implementing blended learning, namely:

1) Live Events (Face-to-Face Learning)

Synchronous direct or face-to-face learning in the same time and place or the same time but different places. The direct/face-to-face learning pattern usually uses a conventional model so that a learning design is needed when face-to-face learning is carried out.

2) Self-Paced Learning (Self Learning)

Self-paced learning allows students to learn anytime and anywhere online. Learning content needs to be specially designed, both text and multimedia, such as: videos, animations, simulations, images, audio, or a combination of all of them.

3) Collaboration (Collaboration)

Collaboration in blended learning learning by combining collaboration between 
teachers and collaboration between students. This collaboration can be enhanced through communication tools, such as forums, chatrooms, discussions, and so on. Through this collaboration, it is expected to improve the construction of students' knowledge and skills.

4) Assessment (Assessment or
Measurement of Learning Outcomes) Assessment is an important step in the implementation of the learning process. The assessment is carried out with the aim of knowing the extent to which the mastery of competencies that have been mastered by students.

5) Performance Support Materials (Support Study Materials)

Teaching materials are one of the important components in supporting the learning process. In learning with blended learning, it should be packaged in digital and printed forms so that it can be accessed by students both face-to-face and online. The use of teaching materials packaged online should also support online learning applications.

Blended learning aims to:

1) Prepare students for good development in the learning process.

2) Provide more practical opportunities for teachers and students to learn independently, be useful, and continue to grow.

3) Combining the best aspects of hands-on learning and online learning.

4) Solve problems in learning with various learning methods.

The advantages of using blended learning are:

1) Learning is more effective and efficient because it combines methods of delivery, teaching models both directly and online, as well as a variety of diverse technological media.

2) Students are easier to access learning materials so that they learn the subject matter independently.

3) Learning can still be done anywhere and anytime.

4) Learning becomes more varied so that the results are optimal because it increases the attractiveness of students in learning

\section{Edmodo}

Edmodo is a platform specifically developed and designed for use by teachers and students in a classroom. Edmodo provides a safe and easy way to communicate and collaborate between students and teachers, sharing content in the form of text, images, links, videos, and audio. Edmodo aims to help educators take advantage of social networking facilities in accordance with learning conditions in the classroom.

Edmodo is a free open source used in education. The features in Edmodo support integrated learning management.

\section{Independent Learning}

Independent learning according to Sugandi (2013) is an attitude of students with the characteristics of taking the initiative to carry out the learning process because of self-motivation and self-will with full responsibility. Mudjiman (2006) argues that independent learning is a student's own initiative to seek learning experiences that are needed by students as a provision for lifelong learning. According to Zamnah (2017), he argues that independent learning is a process that occurs in students influenced by students' thoughts, feelings, strategies used, and student attitudes that lead to learning goals when participating in learning. Based on several theories of learning independence above, it can be concluded that learning independence is a condition where students have the desire and initiative to carry out learning activities, make decisions to overcome learning problems independently with a sense of responsibility.

According to Deswita (2009), there are seven aspects or indicators of learning independence, namely: self-confidence, being able to work independently, being able to make decisions, being responsible, having a desire to compete, being disciplined and active in learning.

The indicators of learning independence can be described through 
several observed aspects, which can be seen in Table 1 below.

Table 1 Aspects observed in the indicators of student learning independence

\begin{tabular}{|c|c|}
\hline Indicator & Observed aspects \\
\hline 1. Confident & $\begin{array}{l}\text { 1.1 } \begin{array}{l}\text { Dare to express } \\
\text { opinions during the }\end{array} \\
\text { learning process } \\
\text { 1.2 } \begin{array}{l}\text { Confident in your own } \\
\text { abilities } \\
\text { 1.3 } \begin{array}{l}\text { Dare to interact with } \\
\text { friends in discussion }\end{array} \\
\text { activities and solve } \\
\text { problems }\end{array}\end{array}$ \\
\hline $\begin{array}{l}\text { 2. Able to } \\
\text { work alone }\end{array}$ & $\begin{array}{l}\text { 2.1 Doing tasks without } \\
\text { being ordered by others } \\
\text { 2.2 } \begin{array}{l}\text { Complete tasks without } \\
\text { asking for help from } \\
\text { others }\end{array} \\
\text { 2.3 } \begin{array}{l}\text { Satisfied with the results } \\
\text { obtained }\end{array} \\
\end{array}$ \\
\hline $\begin{array}{l}\text { 3. Able to } \\
\text { make } \\
\text { decisions }\end{array}$ & $\begin{array}{l}\text { 3.1 Able to solve problems } \\
\text { on their own } \\
\text { 3.2 Be careful in making } \\
\text { decisions }\end{array}$ \\
\hline $\begin{array}{l}\text { 4.Responsibl } \\
\text { e }\end{array}$ & $\begin{array}{l}\text { 4.1 Have self-awareness in } \\
\text { learning } \\
\text { 4.2 Follow the learning } \\
\text { process on time }\end{array}$ \\
\hline $\begin{array}{l}\text { 5. The desire } \\
\text { to compete } \\
\text { ahead }\end{array}$ & 5.1 Have curiosity \\
\hline 6. Discipline & $\begin{array}{ll}6.1 & \text { Follow lessons on time } \\
6.2 & \text { Provide your own } \\
\text { textbook }\end{array}$ \\
\hline $\begin{array}{l}\text { 7. Active in } \\
\text { learning }\end{array}$ & $\begin{array}{l}\text { 7.1 Dare to make } \\
\text { conclusions based on } \\
\text { the explanation of the } \\
\text { material }\end{array}$ \\
\hline
\end{tabular}

\section{Learning outcomes}

The success of education can be seen from student learning outcomes in their studies, where success is largely determined by the quality and accuracy of teachers in choosing learning models and media. In teaching and learning activities, teachers usually set learning goals so that students who succeed in learning are those who succeed in achieving learning goals.

Learning outcomes are a manifestation of learning behavior which is usually seen in changes, habits, skills. Learning outcomes can be seen and measured. Learning outcomes is a term used to indicate something that is achieved by someone after doing an effort.

Learning outcomes are divided into three domains, namely cognitive, affective, and psychomotor. The three domains are distinguished because of their different characteristics. Cognitive relates to the development of students' brain and reasoning abilities. Affective relates to the development of students' feelings and attitudes. While psychomotor relates to the way students develop the two learning outcomes, the three learning outcomes are interrelated. Assessment of learning outcomes is an effort to measure the level of achievement of educational goals which include progress in the thought process, progress in using the five senses and abilities in moral and personality development.

\section{Conclusion}

Blended learning is learning that combines face-to-face learning with elearning. Learning can be done at school directly and also using online learning media. By combining several online media in learning can help teachers to provide meaningful learning (Hardinata A, et al., 2020). Edmodo learning media is a suitable media to use, equipped with various features so that it affects all learning presentation needs and supports online learning activities. Thus, through the application of blended learning assisted by Edmodo, it can increase learning independence and student learning outcomes.

\section{References}

Aulia, L. N., Susilo, S., Subali, B. (2019). Upaya peningkatan kemandirian belajar siswa dengan model problem based learning berbantuan media Edmodo. Jurnal Inovasi Pendidikan IPA, 5 (1); 69-78.

Daryanto. (2013). Media Pembelajaran Perannya Sangat Penting Dalam Mencapai Tujuan Pembelajaran. Yogyakarta: Gava Media.

Dewi, N., Asifa, S. N., Zanthy, L. S. (2020). 


$\begin{array}{lr}\text { PENGARUH } & \text { KEMANDIRIAN } \\ \text { BELAJAR } & \text { TERHADAP HASIL } \\ \text { BELAJAR } & \text { MATEMATIKA. } \\ \text { PYTHAGORAS: Jurnal Program Studi } & \\ \text { Pendidikan Matematika,9(1): } 48-54 .\end{array}$

Fahrulliah, A., Turdjai. (2019). PENERAPAN MODEL BLENDED LEARNING UNTUK MENINGKATKAN KEMANDIRIAN DAN PRESTASI BELAJAR. DIADIK: Jurnal Ilmiah Teknologi Pendidikan, 9 (2); 101-111.

Fisher, M. (2001) Development of a selfdirected learning readiness scale for nursing education. Nurse education today, 21 (7); 516-525.

Graham, C. R. (2005). Blended Learning System. Definisi, Current, and Future Directions. dalam The Hand Book of Blended Learning.

Hardinata, A., Simatupang, H., Hanifa, F., Latip, A., Efwinda, S., \& Yogica, R. (2020). SURVEY ON THE EFFECTIVENESS OF ONLINE LECTURES DURING COVID-19 PANDEMIC: METHODS AND DIFFICULTIES. ISER (Indonesian science education research), 2(2).

Husamah. (2013). Pembelajaran bauran (Blended Learning). Jakarta: Hasil Pustaka.

Mudjiman, H. (2006). Belajar Mandiri (SelfMotivated Learning). Surakarta: LPP UNS dan UNS Press.

Slameto (2010). Belajar dan Faktor-Faktor yang Mempengaruhinya. Jakarta: Rineka Cipta.

Sugandi, A. I. (2013). Pengaruh pembelajaran berbasis masalah dengan setting kooperatif jigsaw terhadap kemandirian belajar siswa SMA. Infinity Journal, 2(2):144-155.

Sugiyono. (2019). Metode Penelitian Pendidikan (Kuantitatif, Kualitatif, Kombinasi, R\&D dan Penelitian pendidikan ) (Apri Nuryanto (ed.); 3rd ed.). Penerbit Alfabeta.

Thorne, K. (2003). Blended Learning: How to Integrate Online and Tradicional Learning. London: Kogan Page Publishers.

Zamnah, L. N. (2017). Hubungan Antara Self-Regulated Learning Dengan
Kemampuan Pemecahan Masalah Matematis Pada Mata Pelajaran Matematika Kelas VIII SMP Negeri3 Cipaku Tahun Pelajaran 2011/2012. Jurnal Teori Dan Riset Matematika (TEOREMA), 1(2), 31-38. 